\title{
Doğu Karadeniz Bölgesinde Çay Tarımı Yapılan Toprakların ve Çay Bitkisinin Azot, Fosfor, Potasyum, Kalsiyum, Magnezyum ve Kükürt Durumları
}

\author{
Mehmet Burak TAȘKIN ${ }^{1} \quad$ Meriç BALCl ${ }^{1} \quad$ Mahmut Reșat SOBA ${ }^{2}$ Emre Can KAYA \\ Pınar ÖZER ${ }^{3} \quad$ Gökhan TANYEL ${ }^{3} \quad$ Ali KABAOĞLU3 \\ Murat Ali TURAN ${ }^{4}$ Süleyman TABAN ${ }^{1 *}$
}

\begin{abstract}
'Ankara Üniversitesi Ziraat Fakültesi Toprak Bilimi ve Bitki Besleme Bölümü, Ankara
${ }^{2}$ Toprak, Gübre ve Su Kaynakları Merkez Araștırma Enstitüsü Müdürlüğü, Ankara

${ }^{3}$ Çay İșletmeleri Genel Müdürlüğü, Atatürk Çay Araștırma Enstitüsü Müdürlüğü, Rize

${ }^{4}$ Uludağ Üniversitesi Ziraat Fakültesi Toprak Bilimi ve Bitki Besleme Bölümü, Bursa
\end{abstract}

\begin{abstract}
*Sorumlu yazar, e-posta (Corresponding author, e-mail): Suleyman.Taban@agri.ankara.edu.tr Geliș tarihi (Received) : 21.08.2015

Kabul tarihi (Accepted) : 04.11.2015
\end{abstract}

\section{Öz}

Doğu Karadeniz Bölgesinde çay tarımı yapılan toprakların ve çay bitkisinin azot, fosfor, potasyum, kalsiyum, magnezyum ve kükürt durumlarını ortaya koyabilmek amacıyla çay tarımı yapılan alanların büyüklüğü dikkate alınarak Artvin bölgesinden 58 (toplam örneğin \% 10,90'ו), Rize bölgesinden 361 (toplam örneğin \% 67,86'sı), Trabzon bölgesinden 101 (toplam örneğin \% 18,98'i), ve Giresun bölgesinden 12 (toplam örneğin \% 2,26'sı) olmak üzere toplam eș zamanlı 532 toprak ve yaprak örneği alınmıștır.

Toprak örneklerinde yapılan analizler sonucu, toplam azot konsantrasyonlarının 0,50-11,06 g/kg arasında değiștiği ve ortalama $2,77 \mathrm{~g} / \mathrm{kg}$ olduğu, bitkiye yarayıșlı fosfor konsantrasyonlarının 1,1 1-337,05 mg/kg arasında değiștiği ve ortalama 45,49 mg/kg olduğu, bitkiye yarayıșlı potasyum konsantrasyonlarının 12,60-3374,53 mg/kg arasında değiștiği ve ortalama 203,90 mg/kg olduğu, bitkiye yarayıșlı kalsiyum konsantrasyonlarının 17,18-50174,33 mg/kg arasında değiștiği ve ortalama 1673,18 mg/kg olduğu, bitkiye yarayıșı magnezyum konsantrasyonlarının 6,30-4999,28 mg/kg arasında değiștiği ve ortalama $215,97 \mathrm{mg} / \mathrm{kg}$ olduğu ve bitkiye yarayıșlı kükürt konsantrasyonlarının ise 4,71-946,41 mg/kg arasında değiștiği ve ortalama 148,94 mg/kg olduğu tespit edilmiștir. Analiz sonuçlarına göre, topraklarda bitkiye yarayıșlı kükürt yönünden sorun görülmezken, \% 4,32'sinde azot, \% 21,99'unda fosfor, \% 37,40'ında potasyum, \% 70,11'inde kalsiyum ve \% 75,00'inde magnezyum noksanlığı belirlenmiștir. Diğer yandan, toprakların \% 75,75'inde azotun ve \% 57,52'sinde fosforun fazla olduğu saptanmıștır.

Doğu Karadeniz Bölgesinde çay tarımı yapılan alanlardan alınan yaprak örneklerinin toplam azot konsantrasyonlarının 25,01-51,53 g/kg arasında değiștiği ve ortalama 41,24 g/kg toplam fosfor konsantrasyonlarının 0,06-0,43 g/kg arasında değiștiği ve ortalama $0,17 \mathrm{~g} / \mathrm{kg}$ toplam potasyum konsantrasyonlarının 0,08-3,46 g/kg arasında değiștiği ve ortalama 0,94 g/kg kalsiyum konsantrasyonlarının 0,07-1,74 $\mathrm{g} / \mathrm{kg}$ arasında değiștiği ve ortalama 0,61 g/kg ve magnezyum konsantrasyonlarının ise $0,04-0,57 \mathrm{mg} / \mathrm{kg}$ arasında değiștiği ve ortalama $0,18 \mathrm{~g} / \mathrm{kg}$ olduğu belirlenmiștir.

Yaprak analiz sonuçlarına göre, yaprak örneklerinin \% 3,46'sında toplam azotun az, buna karșın \% 30,65'inde ise fazla olduğu ve \% 81,77'sinde fosfor, \% 99,81'inde potasyum, \% 17,48'inde kalsiyum ve \% 36,09'unda magnezyum noksanlığı belirlenmiștir.

Anahtar kelimeler: Çay, toprak, yaprak, N, P, K, Ca, Mg, S 


\title{
Nitrogen, Phosphorus, Potassium, Calcium, Magnesium, Sulphur Concentrations of Tea-Farming Soils and Tea Plant Grown in East Black Sea Region
}

\begin{abstract}
With the aim of determining the nitrogen, phosphorus, potassium, calcium, magnesium, sulphur concentration of tea-farming soils and tea plant, 532 soil samples and 532 tea plant leave samples were taken simultaneously along East Black Sea Coastal Region considering the width of the tea cultivated areas (Artvin: 58 samples (10.90\% of total), Rize: 361 (67.86 \%), Trabzon: 101 (18.98\%), Giresun: $12(2.26 \%))$.

At the end of the soil analysis, it was seen that total nitrogen concentration of tea-farming soils varied in the range 0.50-11.06 g/kg with a mean of $2.77 \mathrm{~g} / \mathrm{kg}$, plant available phosphorus: 1.11 $337.05 \mathrm{mg} / \mathrm{kg}$ with a mean of $45.49 \mathrm{mg} / \mathrm{kg}$, plant available potassium: $12.60-3374.53 \mathrm{mg} / \mathrm{kg}$ with a mean of $203.90 \mathrm{mg} / \mathrm{kg}$, plant available calcium: $17.18-50174.33 \mathrm{mg} / \mathrm{kg}$ with a mean of 1673.18 mg/kg, plant available magnessium: $6.30-4999.28 \mathrm{mg} / \mathrm{kg}$ with a mean of $215.97 \mathrm{mg} / \mathrm{kg}$ and plant available sulphur: $4.71-946.41 \mathrm{mg} / \mathrm{kg}$ with a mean of $148.94 \mathrm{mg} / \mathrm{kg}$. Considering analysis results, plant available sulphur concentration of the soil samples was found enough for the tea plant, however in $4.32 \%$ of the soil, nitrogen concentration; in $21,99 \%$, phosphorus concentration; in $37.40 \%$, potassium concentration; in $70.11 \%$, calcium concentration; in $75.00 \%$, magnessium concentration were found insufficient. On the other hand, in $75.75 \%$ of the soil, nitrogen concentration and in $57.52 \%$, phosphorus concentration were excessively found.

It was determined that total nitrogen concentration of tea leaves taken from East Black Sea Region varied in the range $25.01-51.53 \mathrm{~g} / \mathrm{kg}$ with a mean of $41.24 \mathrm{~g} / \mathrm{kg}$, phosphorus concentration: 0.06$0.43 \mathrm{~g} / \mathrm{kg}$ with a mean of $0.17 \mathrm{~g} / \mathrm{kg}$, potassium concentration: $0.08-3.46 \mathrm{~g} / \mathrm{kg}$ with a mean of 0.94 $\mathrm{g} / \mathrm{kg}$, calcium concentration: 0.07-1.74 g/k with a mean of $0.61 \mathrm{~g} / \mathrm{kg}$ and magnessium concentration: $0.04-0.57 \mathrm{mg} / \mathrm{kg}$ with a mean of $0.18 \mathrm{~g} / \mathrm{kg}$. At the end of the analysis, total nitrogen concentration was not enough in $3.46 \%$ of the tea leave samples, however it was found excessive in $30.65 \%$. In $81.77 \%$ of tea leave samples phosphorus concentration, in $99.81 \%$, pottassium concentration, in $17.48 \%$, calcium concentration, in $36.09 \%$, magnessium concentration were found insufficient.
\end{abstract}

Key Words: Tea, , leave, soil, N, P, K, Ca, Mg, S

\section{Gíriș}

Ülkemizde çay tarımı, Doğu Karadeniz Bölgesinde Gürcistan sınırında bulunan SarpHopa'dan bașlayarak Fatsa-Ordu'ya kadar uzanan sahil șeridinde yaklașık 76600 ha'lık bir alanda yapılmaktadır. Çay alanları ve üretim değerleri dikkate alınarak yapılan değerlendirmede; Rize (toplam çaylıkların \% 65,2'si) ilk sırada yer almakta olup, bunu sırasıyla Trabzon (toplam çaylıkların \% 20,7'si), Artvin (toplam çaylıkların \% 11,2'si) ve Giresun (toplam çaylıkların \% 5,6'sı) illeri takip etmektedir.

1930'lu yıllarda bașlayan, 1970'li yıllarda önemi giderek artan ve bölgenin en önemli geçim kaynağını olușturan çay üretimimiz, Doğu Karadeniz insanının yașam biçimini olușturmuștur. Dünya genelinde 45 ülkede toplam 2.461.000 ha alanda çay üretimi yapılmaktadır. Çay üretim alanları sıralamasında Çin 943.000 ha alanla birinci sırada, Türkiye ise 77.000 ha alanla Hindistan, Sri Lanka, Kenya ve Endonezya'nın ardından b'ıncı sırada bulunmaktadır. 
Çay bitkisi (Camellia sinensis L.) genelde bol yağıșlı ve yağıșın yıl içerisindeki dağıımı düzgün, sıcak ve toprak reaksiyonu asit olan $(\mathrm{pH} 4,5-6)$ yörelerde ekonomik olarak yetiștirilebilmektedir. Çayın ekolojik istekleri dikkate alındığında, çayın ülkemizde Doğu Karadeniz Bölgesinde ekonomik olarak yetiștirilebileceği anlașılmıș ve çay tarımı için gerekli girișimler 1930'lu yıllarda bașlamıștır.

Türkiye'de ilk çaylıklar 1938 yılında tohumdan yetiștirilen fidanlarla kurulmuș, daha sonraki yıllarda çay tarımı yapılan alanlar hızla artmıș 77.000 ha'a kadar ulașmıș, ancak 2008 krizinden sonra çay tarımı yapılan alanlarda gerileme olmuș ve günümüzde 75.890 ha'lık bir alana ulașmıștır (Anonim, 2012).

Bu kadar öneme sahip bir bitkinin yetiștirildiği, toprakların verimlilik durumlarının bilinmesinin yanı sıra bu verimliliğin devam edip etmediğinin de izlenmesi gerekmektedir. Nitekim bölgede çay üreticilerinin gübre kullanım bilincinin tam olarak olușmadığını söylemek mümkündür. Gerçekten de çay tarımı yapılan toprakların yıllara göre ortalama olarak \% 5'inde azot noksanlığı görülürken, \% 70'inden fazlasında azot fazlalığı görülmektedir (Taban vd., 2006). Benzer șekilde yine toprakların 1978-1982 yılları arasında toprakların \% 83'ünde fosfor noksanlığı görülürken, 2005 yılında toprakların \% 69'unda fosfor fazlalığı belirlenmiștir (Taban vd., 2006). Diğer yandan yörede așırı azotlu gübre kullanımı sonucu toprakların giderek asitleșmesine bağlı olarak topraklarda potasyum, kalsiyum ve magnezyum noksanlığının da görülmesi kaçınılmaz olmaktadır.

Bu çalıșmada amaçlanan; Doğu Karadeniz Bölgesi' nde çay tarımı yapılan Artvin, Rize, Trabzon ve Giresun illerinden alınan toprak ve yaprak örneklerinde azot, fosfor, potasyum, kalsiyum ve magnezyum analizleri yaparak, çay topraklarının ve çay bitkisinin beslenme durumunu ortaya koymaktır.

\section{MATERYAL ve YÖNTEM}

\section{Örnekleme, Örnek Alınan Yerlerin Seçimi ve Toprak Örneklerinin Alınması}

Araștırmada kullanılan toprak ve yaprak örnekleri eș zamanlı olarak Artvin, Rize, Trabzon ve Giresun illerinde çay tarımı yapılan alanların büyüklükleri, yayılıșları (sahil, orta yüksek ve yüksek alanlar), iklim koșulları ve hasatların tamamlanmıș olması yanında, yörede çay tarımı yapılan alanları temsil edebilecek nitelikte ve sayıda olması da dikkate alınarak 16-22 Aralık 2012, 3-9 Șubat 2013 ve 15-17 Șubat 2013 tarihlerinde 3 farklı dönemlerde alınmıștır.

Çaylıkların yayılıș alanları dikkate alınarak Artvin'den 3 ilçeden 58 (toplamın \% 10,9'u), Rize'den 11 ilçeden 361 (toplamın \% 67,86'sı), Trabzon'dan 5 ilçeden 101 (toplamın \% 18,98'i) ve Giresun'dan 2 ilçeden 12 (toplamın \%2,26'sı) olmak üzere toplam 532 noktadan toprak (0-30 $\mathrm{cm})$ ve toprak örneği alınan alanlarda bulunan çay bitkilerinin birinci yıl sürgünlerinden de eș zamanlı olarak yaprak örnekleri alınmıștır.

\section{Toprak Örneklerinin Laboratuvar Analizlerine Hazırlanması}

Farklı yerlerden alınan toprak örnekleri, polietilen yaygılar üzerinde güneș görmeyen gölge bir yerde havada kuru duruma gelinceye dek kurutulmuș, iri kesekler ezilmiș, 2 mm'lik elekten geçirilmiș ve ağzı plastik kapakla kapalı cam kavanozlarda saklanmıștır. Toprak örneğinin alınması sırasında ve analize hazırlanması așamalarında çeșitli nedenlerle ortaya çıkabilecek bulașmaları önlemek için gerekli özen gösterilmiștir.

\section{Toprak Analizleri}

Çalıșma kapsamında alınan toprak örneklerinde toplam azot Kjeldahl yöntemine göre (Bremner, 1965); bitkiye yarayıșlı fosfor Bray ve Kurtz (1945) tarafından geliștirilen Bray ve Kurtz No:1 yöntemine göre yapıımıștır. Ekstrakt çözeltisi olarak $0,03 \mathrm{~N} \mathrm{NH}_{4} \mathrm{~F}+0,025 \mathrm{~N} \mathrm{HCl}$ kullanılmıș ve toprak:çözelti oranı 1:7 olacak șekilde hazırlanan karıșım 1 dakika çalkalanmıștır. Süzükteki fosfor miktarı, ICP-OES (Inductively Coupled PlasmaOptical Emission Spectrometry, Perkin Emler Model DV 2100 ) cihazı ile belirlenmiștir (Boss ve Fredeen, 2004). Bitkiye yarayıșlı potasyum, kalsiyum ve magnezyum, Pratt (1965) tarafından bildirildiği șekilde toprak örneği 1,0 N nötr (7.0) amonyum asetat ile ekstrakte edilerek süzükteki potasyum, kalsiyum ve magnezyum ICP-OES cihazı ile belirlenmiștir (Boss ve Fredeen, 2004). Bitkiye yarayıșlı kükürt $\left(\mathrm{SO}_{4}-\mathrm{S}\right)$, Bardslay ve Lancaster (1965)' e göre toprak örneğinin 0,5 $\mathrm{N} \mathrm{NH}_{4} \mathrm{Oac}+$ $0,25 \mathrm{~N}$ HOAc çözeltisi ile ekstrakte edilmesi sonucunda elde edilen toprak çözeltisindeki $S$ miktarı, ICP-OES cihazı ile belirlenmiștir (Boss ve Fredeen, 2004). 


\section{Bitki Örneklerinin Laboratuvar Analizlerine Hazırlanması}

Toprak örnekleri ile eș zamanlı olarak alınan yaprak örnekleri ile tarla denemelerinden elde edilen yaprak örnekleri kese kağıtları içerisinde laboratuvara getirilmiș, saf su ile yıkanmıș ve 65 ${ }^{0} C^{\prime}$ de durağan ağırlığa gelene hava sirkülasyonlu kurutma dolabında kurutulmuștur. Öğütülen çay yaprak örnekleri polietilen torbalara aktarılmıș ve etiketlenmiștir. Yaprak örneklerinin analize hazır hale getirilmesi așamalarında olası bulașmalara karșı gereken özen gösterilmiștir. Öğütülen çay yaprak örnekleri Berghof-MWS-2 Model 24 yakma üniteli mikrodalga örnek parçalayıcıda nitrik asit ile yaș yakılmıștır (Boss ve Fredeen 2004).

\section{Bitki Analizleri}

Çalıșma kapsamında toplanan çay yaprak örneklerinde toplam azot Kjeldahl yöntemine (Bremner, 1965); toplam fosfor, potasyum, kalsiyum ve magnezyum ise mikrodalga firında yaș yakma suretiyle hazırlanan süzükte ICP-OES (Inductively Coupled Plasma-Optical Emission Spectrometry, Perkin Emler Model DV 2100) cihazı ile belirlenmiștir (Boss ve Fredeen, 2004).

\section{Analiz Sonuçlarının Değerlendirilmesi}

Çay tarımı yapılan 4 ilden alınan toprak ve çay yaprak örneklerinde yapılan analiz sonuçlarına göre elde edilen bulgular yeterlilik sınıflarına göre değerlendirilmiștir.

\section{BULGULAR ve TARTIȘMA}

\section{Toprak Analiz Sonuçları}

Doğu Karadeniz Bölgesinde çay tarımı yapılan alanlardan alınan toplam 532 toprak örneğinde toplam azot miktarının 0,50-11,06 g/kg; bitkiye yarayıșı ı fosfor konsantrasyonlarının 1,11337,05 mg/kg; bitkiye yarayıșlı potasyum konsantrasyonlarının 12,60-3374,53 mg/kg; bitkiye yarayıșlı kalsiyum konsantrasyonlarının 17,18-
50174,33 mg/kg; bitkiye yarayıșlı magnezyum konsantrasyonlarının 6,30-4999,28 mg/kg; bitkiye yarayıșlı kükürt konsantrasyonlarının ise 4,71$946,41 \mathrm{mg} / \mathrm{kg}$ arasında değiștiği belirlenmiștir (Çizelge 1).

Sarımehmet ve Müftüoğlu (1993) Doğu Karadeniz Bölgesi' nde çay tarımı yapılan alanlardan aldıkları 1182 toprak örneğinde yapılan analizler sonucu, toprakların yeterli düzeyde toplam azot içerdiklerini saptamıșlardır. Taban vd., (2001) Rize yöresinde çay tarımı yapılan alanın toplam azot miktarını 2,0 g/kg olarak belirlemișlerdir. Kacar vd., (1979) Doğu Karadeniz Bölgesinde çay tarımı yapılan alanlardan aldıkları 30 toprak örneğinde bitkiye yarayıșı fosfor miktarını Bray and Kurtz (1945) yöntemine göre 1,1 mg/kg ile 77,1 mg/kg arasında değiștiğini ve ortalama olarak 15,2 mg/kg olarak belirlemișlerdir. Kacar vd., (1978) ülkemizde çay tarımı yapılan toprakların orta düzeyde bitkiye yarayıșlı potasyum içerdiğini rapor etmișlerdir.

Bu çalıșma kapsamındaki illerden alınan toprak örneklerinde tespit edilen toplam azot miktarları incelendiğinde; $2,24 \mathrm{~g} / \mathrm{kg}$ ile en düșük Trabzon ilinde belirlenmiș ve bunu sırasıyla Artvin, Rize ve Giresun illeri takip etmiștir. En düșük bitkiye yarayıșlı fosfor konsantrasyonu $28,71 \mathrm{mg} / \mathrm{kg}$ ile Artvin ilinden alınan toprak örneklerinde belirlenmiș ve bunu sırasıyla Trabzon, Rize ve Giresun illeri izlemiștir. Bitkiye yarayıșlı potasyum konsantrasyonları bakımından yine Artvin ilinden en düșük değer (135, 90 mg/kg) elde edilmiș ve bunu sırasıyla Trabzon, Giresun ve Rize illeri takip etmiștir.

Bitkiye yarayıșlı ortalama kalsiyum, magnezyum ve kükürt konsantrasyonları en düșük Artvin (sırasıyla $857,17 \mathrm{mg} / \mathrm{kg} ; 147,30 \mathrm{mg} / \mathrm{kg}$ ve 68,92 $\mathrm{mg} / \mathrm{kg}$ ) ilinde belirlenmiș ve bunu sırasılyla diğer iller takip etmiștir (Çizelge 2).

Çizelge 1 . Doğu Karadeniz Bölgesinde çay tarımı yapılan alanlardan alınan toprak örneklerinin toplam N, bitkiye yarayıșlı P, K, Ca, Mg ve S konsantrasyonları

Table 1. Total N, plant available P, K, Ca, Mg and S concentrations of soil samples taken from the area of tea cultivation in the Eastern Black Sea Region

\begin{tabular}{lcccccc}
\hline Değerler & $\begin{array}{c}\mathrm{N} \\
(\mathrm{g} / \mathrm{kg})\end{array}$ & $\begin{array}{c}\mathrm{P} \\
(\mathrm{mg} / \mathrm{kg})\end{array}$ & $\begin{array}{c}\mathrm{K} \\
(\mathrm{mg} / \mathrm{kg})\end{array}$ & $\begin{array}{c}\text { Ca } \\
(\mathrm{mg} / \mathrm{kg})\end{array}$ & $\begin{array}{c}\mathrm{Mg} \\
(\mathrm{mg} / \mathrm{kg})\end{array}$ & $\begin{array}{c}\mathrm{S} \\
(\mathrm{mg} / \mathrm{kg})\end{array}$ \\
\hline En Düșük & 0,50 & 1,11 & 12,60 & 17,18 & 6,30 & 4,71 \\
\hline En Yüksek & 11,06 & 337,05 & 3374,53 & 50174,33 & 4999,28 & 946,41 \\
\hline Ortalama & 2,77 & 45,49 & 203,90 & 1673,18 & 215,97 & 148,94 \\
\hline
\end{tabular}


Çizelge 2. Çay tarımı yapılan illerden alınan toprak örneklerinin toplam N, bitkiye yarayıșlı P, K, Ca, Mg ve S konsantrasyonları

Table 2. Total N, plant available P, K, Ca, Mg and S concentrations of soil samples taken from the province of tea cultivation

\begin{tabular}{|c|c|c|c|c|c|c|c|}
\hline İ & İlçe & $\begin{array}{c}N \\
(g / k g)\end{array}$ & $\begin{array}{c}\mathrm{P} \\
(\mathrm{mg} / \mathrm{kg})\end{array}$ & $\begin{array}{c}\mathrm{K} \\
(\mathrm{mg} / \mathrm{kg})\end{array}$ & $\begin{array}{c}\text { Ca } \\
(\mathrm{mg} / \mathrm{kg})\end{array}$ & $\begin{array}{c}\mathrm{Mg} \\
(\mathrm{mg} / \mathrm{kg})\end{array}$ & $\begin{array}{c}\mathrm{S} \\
(\mathrm{mg} / \mathrm{kg})\end{array}$ \\
\hline \multirow{4}{*}{$\sum_{\substack{c \\
\infty}}^{\infty}$} & Hopa (23) & 2,39 & 17,46 & 145,36 & 882,17 & 190,56 & 67,29 \\
\hline & Borçka (15) & 2,14 & 52,47 & 102,10 & 777,17 & 102,45 & 62,70 \\
\hline & Arhavi (20) & 2,61 & 23,85 & 150,36 & 888,27 & 131,18 & 76,76 \\
\hline & Ortalama & 2,40 & 28,71 & 135,90 & 857,11 & 147,30 & 68,92 \\
\hline \multirow{12}{*}{$\begin{array}{l}\stackrel{N}{\bar{D}} \\
\stackrel{m}{m}\end{array}$} & Fındıklı (26) & 2,65 & 50,96 & 118,62 & 799,10 & 96,40 & 52,29 \\
\hline & Ardeșen (52) & 3,80 & 85,11 & 161,80 & 844,14 & 101,61 & 67,92 \\
\hline & Pazar (44) & 2,59 & 22,09 & 495,50 & 9966,22 & 891,89 & 257,68 \\
\hline & Hemșin (9) & 2,12 & 45,71 & 82,64 & 991,35 & 89,70 & 199,34 \\
\hline & Cayeli (64) & 3,70 & 57,12 & 240,58 & 1248,37 & 208,79 & 448,47 \\
\hline & Merkez (82) & 2,19 & 38,72 & 187,77 & 1051,44 & 156,69 & 143,88 \\
\hline & Güneysu (22) & 2,25 & 53,43 & 96,12 & 268,73 & 30,43 & 100,81 \\
\hline & Derepazarı (12) & 3,17 & 42,00 & 226,42 & 358,58 & 61,07 & 111,29 \\
\hline & lyıdere (15) & 3,56 & 66,73 & 187,19 & 425,11 & 58,58 & 88,29 \\
\hline & Kalkandere (30) & 3,11 & 47,52 & 230,45 & 842,68 & 190,99 & 68,62 \\
\hline & İkizdere (5) & 3,18 & 123,45 & 88,17 & 95,17 & 25,99 & 49,66 \\
\hline & Ortalama & 2,95 & 51,77 & 221,14 & 1996,04 & 227,68 & 144,39 \\
\hline \multirow{6}{*}{$\begin{array}{l}\frac{c}{0} \\
\text { N } \\
\stackrel{0}{0} \\
\stackrel{\mathbb{N}}{=}=\end{array}$} & Of $(60)$ & 2,27 & 32,37 & 200,57 & 1092,40 & 251,67 & 71,27 \\
\hline & Hayrat (17) & 1,98 & 31,40 & 205,02 & 1356,06 & 251,07 & 116,86 \\
\hline & Dernekpazarı (3) & 2,87 & 45,02 & 238,93 & 1680,30 & 159,90 & 42,54 \\
\hline & Sürmene (15) & 2,17 & 21,89 & 113,31 & 282,80 & 60,49 & 138,35 \\
\hline & Araklı (6) & 2,63 & 23,02 & 91,45 & 1379,11 & 140,91 & 35,95 \\
\hline & Ortalama & 2,24 & 30,47 & 183,01 & 1051,04 & 213,87 & 81,00 \\
\hline \multirow{3}{*}{ 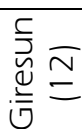 } & Eynesil (5) & 3,93 & 52,30 & 103,38 & 891,63 & 278,20 & 99,02 \\
\hline & Tirebolu (7) & 2,83 & 72,83 & 251,34 & 1319,49 & 166,92 & 47,23 \\
\hline & Ortalama & 3,28 & 64,27 & 189,69 & 1141,21 & 213,29 & 73,12 \\
\hline
\end{tabular}

\section{Toprak Örneklerinin Makro Element Bakımından Genel Durumu ve Dağılımı}

Toplam 532 toprak örneğinde belirlenen toplam azot miktarı yeterlilik sınırlarına göre sınıflandırıldığında; toprakların \% 4,32'inde azotun az, \% 19,92'sinde yeterli, \% 44, 92'sinde fazla ve \% 30,83'ünde ise çok fazla sınıfında olduğu belirlenmiștir (Çizelge 3). Doğu Karadeniz Bölgesi' nde çay yetiștirilen toprakların toplam azot miktarları yıllara göre değișiklik göstermektedir. 1978-1982 yılları arasında çaylıklardan alınan 1673 toprak örneğinin \% 73'ünde, 1989 yılında 132 toprak örneğinin \% 30'unda, 1994-1999 yılları arasında toplam 7398 toprak örneğinin \% 81'inde, 20012004 yılları arasında toplam 1629 toprak örneğinin \% 64'ünde ve 2005 yılında alınan 90 toprak örneğinin \% 93'ünde toplam azotun fazla ve çok fazla düzeyde olduğu belirlenmiștir (Taban vd., 2006). Aynı yıllarda yapılan toprak analiz sonuçlarına göre azot noksanlığı görülen alanların son derece az olması, çay tarımı yapılan topraklarda așırı azotlu gübre kullanıldığı sonucunu ortaya çıkarmaktadır. Bölgede genelde çay üreticisinin önerilen dozların üzerinde kimyasal gübre kullandığı bilinmektedir (Mahmutoğlu, 1994). Dengesiz gübre kullanımı sonucu çay tarımı yapılan topraklarda düșük oranlarda da olsa azot noksanlığı görülebilmektedir. Așırı azotlu gübre kullanımı bir yandan ekonomik kayba, çevre kirliliğine, su kaynaklarında nitrat kirlenmesine neden olurken, diğer yandan da özellikle amonyum sülfat gübresi toprakların pH'sını düșürerek daha da asitleșmesine neden olmakta, bol ve kaliteli yaș çay yaprağının alınmasına engel olmaktadır.

Toplam 532 toprak örneğinde belirlenen bitkiye yarayıșı fosfor konsantrasyonu yeterlik sınırlarına göre sınıflandırıldığında; toprakların \% 21, 99'unda fosforun çok az-az, \% 20,49'unda orta ve \% 57,52'sinin de yüksek sınıfında olduğu belirlenmiștir (Çizelge 3). Doğu Karadeniz Bölgesi' nde çay tarımı yapılan toprakların bitkiye yarayıșı fosfor miktarları yıllara göre değișiklik göstermektedir. 1978-1982 yılları arasında çaylıklardan alınan 1544 toprak örneğinin \% 83'ünde, 1989 yılında 137 toprak 
Örneğinin \% 48'inde, 1994-1999 yılları arasında toplam 7386 toprak örneğinin \% 34'ünde, 20012004 yılları arasında toplam 1635 toprak örneğinin $\%$ 37'sinde ve 2005 ylında ise 90 toprak örneğinin $\% 31$ 'inde fosfor noksanlığı belirlenmiștir (Taban vd., 2006). Yurtsever ve Alkan (1975) çay tarımının mevcut olduğu toprakların \% 73'ünde fosforun yetersiz olduğunu ve bu nedenle fosforlu gübreye intiyaç duyulduğunu rapor etmiștir. 1993 yllında; Doğu Karadeniz Bölgesinde çay yetiștirilen toprakların \% 63,47'sinde bitkiye yarayıșlı fosfor miktarının çok az, \% 17,08'inde ise az olduğu belirtilmiștir (Müftüoğlu ve Sarımehmet, 1993). 1998 yılında yapılan çalıșmaya göre ise çay tarımı yapılan ve yapılmayan toprakların \% 81,8'inde yarayıșlı fosforun az olduğu rapor edilmiștir (Müftüoğlu ve Sarımehmet, 1998). Çalıșmada en fazla fosfor noksanlığının \% 33,34 ile Giresun ilinden alınan topraklarda olduğu belirlenmiștir. Bunu sırasıyla \% 28,71 ile Trabzon, \% 22,41 ile Artvin ve \% 19,66 ile
Rize illeri izlemiștir (Çizelge 3). Müftüoğlu ve Sarımehmet (1993) Rize ilinden alınan 1271 toprak örneğinin \% 84, 19 'unda, Artvin ilinden alınan 200 toprak örneğinin \% 73'ünde ve Trabzon, Giresun ve Ordu illerinden alınan toplam 344 toprak örneğinin \% 45,35'inde fosfor noksanlığının olduğunu rapor etmișlerdir.

Alınan toplam 532 toprak örneği, bitkiye yarayıșılı potasyum konsantrasyonu yeterlik sınırlarına göre sınıflandırıldığında toprakların \% 37,40'ında potasyumun çok az-az, toprakların \% 44,74'ünde orta ve \% 17,86'sında iyi-fazla sınıfında olduğu belirlenmiștir (Çizelge 3). Çay tarımı yapılan bu bölgenin topraklarının bitkiye yarayıșlı potasyum miktarları yıllara göre değișiklik göstermektedir. 1978-1982 yılları arasında çaylıklardan alınan 1180 toprak örneğinin \% 33'ünde, 1994-1999 yılları arasında alınan toplam 7397 toprak örneğinin \% 21'inde, 2001-2004 yılları arasında alınan toplam

Çizelge 3. Cay tarımı alanlarından alınan toprak örneklerinde belirlenen toplam N, bitkiye yarayıșlı P, K, Ca ve Mg konsantrasyonlarının yeterlik sınırlarına göre dağıımı

Table 3. Distribution of determined total $\mathrm{N}$, plant available $P, K$, Ca and $\mathrm{Mg}$ concentrations of the soil samples taken from tea areas according to the limits of adequacy

\begin{tabular}{|c|c|c|c|c|c|c|c|}
\hline \multirow{2}{*}{ Makro Element } & \multirow{2}{*}{ Sınır Değeri } & \multirow{2}{*}{ Sinıf } & \multicolumn{5}{|c|}{ Dağılım \% } \\
\hline & & & Artvin & Rize & Trabzon & Giresun & Genel \\
\hline \multirow{5}{*}{$\begin{array}{c}\mathrm{N}(\mathrm{g} / \mathrm{kg}) \\
\text { (Brenmer, 1965) }\end{array}$} & $<0,45$ & Cok az & 0 & 0 & 0 & 0 & 0 \\
\hline & $0,45-0,90$ & $\mathrm{Az}$ & 3,45 & 2,22 & 11,88 & 8,33 & 4,32 \\
\hline & $0,90-1,70$ & Yeterli & 27,59 & 18,28 & 22,77 & 8,33 & 19,92 \\
\hline & $1,70-3,20$ & Fazla & 46,55 & 44,32 & 47,52 & 33,33 & 44,92 \\
\hline & $>3,20$ & Çok fazla & 22,41 & 35,18 & 17,82 & 50,00 & 30,83 \\
\hline $\mathrm{P}(\mathrm{mg} / \mathrm{kg})$ & $<3$ & Çok az & 8,62 & 8,86 & 15,84 & 16,67 & 10,34 \\
\hline (Bray ve Kurtz 1945) & $3-7$ & $\mathrm{Az}$ & 13,79 & 10,80 & 12,87 & 16,67 & 11,65 \\
\hline \multirow{2}{*}{$\begin{array}{c}\text { (Olsen ve Sommers, } \\
\text { 1982) }\end{array}$} & $7-20$ & Orta & 29,31 & 18,01 & 25,74 & 8,33 & 20,49 \\
\hline & $>20$ & Yüksek & 48,28 & 62,33 & 45,54 & 58,33 & 57,52 \\
\hline \multirow{5}{*}{$\begin{array}{c}\mathrm{K}(\mathrm{mg} / \mathrm{kg}) \\
(\mathrm{FAO}, 1990)\end{array}$} & $<50$ & Çok az & 10,34 & 10,25 & 9,90 & 0,00 & 9,96 \\
\hline & $50-100$ & $\mathrm{Az}$ & 32,76 & 27,42 & 24,75 & 25,00 & 27,44 \\
\hline & $100-300$ & Orta & 48,28 & 42,11 & 49,50 & 66,67 & 44,74 \\
\hline & $300-1000$ & İyi & 8,62 & 2,22 & 14,85 & 8,33 & 16,17 \\
\hline & $>1000$ & Fazla & 0,00 & 18,01 & 0,99 & 0,00 & 1,69 \\
\hline \multirow{5}{*}{$\begin{array}{l}\mathrm{Ca}(\mathrm{mg} / \mathrm{kg}) \\
\text { (NH}{ }_{4} \text {-Asetat) } \\
(\mathrm{FAO}, 1990)\end{array}$} & $<380$ & Çok az & 44,83 & 46,54 & 47,52 & 16,67 & 45,86 \\
\hline & $380-1150$ & $A z$ & 29,31 & 21,88 & 26,73 & 50,00 & 24,25 \\
\hline & $1150-3500$ & Yeterli & 24,14 & 20,22 & 17,82 & 33,33 & 20,68 \\
\hline & 3500-10000 & Fazla & 1,72 & 11,36 & 7,92 & 0,00 & 6,77 \\
\hline & $>10000$ & Çok fazla & 0,00 & 0,00 & 0,00 & 0,00 & 2,44 \\
\hline \multirow{5}{*}{$\begin{array}{c}\mathrm{Mg}(\mathrm{mg} / \mathrm{kg}) \mathrm{NH}_{4^{-}} \\
\text {Asetat) } \\
(\mathrm{FAO}, 1990)\end{array}$} & $<50$ & Çok az & 46,55 & 42,38 & 38,61 & 8,33 & 41,35 \\
\hline & $50-160$ & $A z$ & 27,59 & 32,41 & 39,60 & 50,00 & 33,65 \\
\hline & $160-480$ & Yeterli & 17,24 & 16,07 & 9,90 & 33,33 & 15,41 \\
\hline & $480-1500$ & Fazla & 8,62 & 5,82 & 8,91 & 8,33 & 6,77 \\
\hline & $>1500$ & Çok fazla & 0,00 & 3,32 & 2,97 & 0,00 & 2,82 \\
\hline \multirow{2}{*}{$\begin{array}{c}\mathrm{S} \text { (mg/kg) } \\
\text { (Bardslay ve } \\
\text { Lancaster, 1965) }\end{array}$} & $<10$ & $\mathrm{Az}$ & 0,00 & 0,55 & 2,97 & 0,00 & 0,94 \\
\hline & $>10$ & Fazla & 100,00 & 99,45 & 97,03 & 100,00 & 99,06 \\
\hline
\end{tabular}


1640 toprak örneğinin \% 24'ünde ve 2005 yllında alınan 90 toprak örneğinin \% 12'sinde potasyum noksanlığı belirlenmiștir (Taban vd., 2006). Müftüoğlu ve Sarımehmet (1998) tarafından yapılan çalıșmaya göre ise çay tarımı yapılan ve yapılmayan toprakların \% 32,4'ünde yarayıșlı potasyumun az olduğu rapor edilmiștir. Çizelge 3'de çalıșmamızda incelenen illerden alınan toprak örnekleri analiz sonuçlarına göre; en fazla potasyum noksanlığının $\%$ 43, 10 ile Artvin ilinde belirlendiği ve bunu sırasıyla $\%$ 37,67 ile Rize, \% 34,65 ile Trabzon, \% 25 ile Giresun ilinin izlediği görülmektedir.

Bitkiye yarayıșlı kalsiyum konsantrasyonu bakımından; çalıșma alanları topraklarının \% 70, 11 inde kalsiyumun çok az-az, \% 20,68'inde yeterli ve \% 9,21'inde ise fazla-çok fazla sınıfinda yer aldığı belirlenmiștir (Çizelge 3). En fazla kalsiyum noksanlığı \% 74,25 ile Trabzon ilinde belirlenmiștir. Bunu sırasıyla \% 74, 14 ile Artvin, \% 68, 42 ile Rize ve \% 66,67 ile Giresun izlemiștir (Çizelge 3).

Toprak örneklerinin bitkiye yarayıșı magnezyum konsantrasyonu analiz sonuçlarına göre; \% 75'inin çok az-az, \% 15,41'inin yeterli ve \% 9,59'unun ise fazla-çok fazla sınıfta olduğu belirlenmiștir. En fazla magnezyum noksanlığı \% 78,21 ile Trabzon ili topraklarında tespit edilmiștir. Bunu sırasıyla \% 74,79 ile Rize, \% 74, 14 ile Artvin ve \% 58,33 ile Giresun illeri izlemiștir. Bu çalıșma kapsamında yer alan illerin topraklarının bitkiye yarayıșlı kükürt konsantrasyonu yönünden önemli bir sorununun olmadığı belirlenmiștir (Çizelge 3).

\section{Çay Bitkisi Yaprak Analiz Sonuçları}

Doğu Karadeniz Bölgesi' nde çay tarımı yapılan alanlardan toprak örnekleri ile birlikte eș zamanlı olarak alınan yaprak örneklerinin toplam azot konsantrasyonunun 25,01-51,53 g/kg ve ortalama $41,24 \mathrm{~g} / \mathrm{kg}$, fosfor konsantrasyonunun 0,06-0,43 $\mathrm{g} / \mathrm{kg}$ ve ortalama $0,17 \mathrm{~g} / \mathrm{kg}$, toplam potasyum konsantrasyonunun 0,08-3,46 $\mathrm{g} / \mathrm{kg}$ ve ortalama $0,94 \mathrm{~g} / \mathrm{kg}$, kalsiyum konsantrasyonunun 0,07-1,74 $\mathrm{g} / \mathrm{kg}$ ve ortalama $0,61 \mathrm{~g} / \mathrm{kg}$ ve magnezyum konsantrasyonunun ise $0,04-0,57 \mathrm{~g} / \mathrm{kg}$ arasında değiștiği ve ortalama olarak $0,18 \mathrm{~g} / \mathrm{kg}$ olduğu belirlenmiștir (Çizelge 4).
Doğu Karadeniz Bölgesinde çay tarımı yapılan alanlardan toprak örnekleri ile birlikte eș zamanlı olarak alınan yaprak örneklerinin toplam fosfor, potasyum, kalsiyum ve magnezyum konsantrasyonlarının bölgelere göre durumu Çizelge 5'de verilmiștir

Çizelge 5'de görüldüğü gibi, yaprak örneklerinin ortalama toplam azot konsantrasyonu en az 42,71 $\mathrm{g} / \mathrm{kg}$ ile Artvin ilinde belirlenmiș, bunu sırasıyla Trabzon $(46,13 \mathrm{~g} / \mathrm{kg})$, Rize $(47,58 \mathrm{~g} / \mathrm{kg})$ ve Giresun $(52,90 \mathrm{~g} / \mathrm{kg})$ illeri takip etmiștir. Toplam fosfor konsantrasyonu en az 1,37 g/kg ile Trabzon ilinde belirlenmiș ve bu ili Giresun (1,38 g/kg), Artvin $(1,62 \mathrm{~g} / \mathrm{kg})$ ve Rize $(1,84 \mathrm{~g} / \mathrm{kg})$ takip etmiștir. Toplam potasyum konsantrasyonu az $8,09 \mathrm{~g} / \mathrm{kg}$ ile Giresun'dan toplanan yaprak örneklerinde belirlenmiștir. Bunu sırasıyla Trabzon, Artvin ve Rize illeri takip etmiștir. Yaprak örnekleri toplam kalsiyum konsantrasyonu analiz sonucuna göre; en az 5,53 $\mathrm{g} / \mathrm{kg}$ ile Trabzon ilinde saptanmıș ve bu ili sırasıyla Giresun, Rize ve Artvin illeri takip etmiștir. Toplam magnezyum konsantrasyonu bakımından en az değer 1,50 g/kg ile Trabzon ilinde belirlenmiș olup, bunu sırasıyla 1,81 g/kg ile Artvin ve Rize illeri, 1,96 $\mathrm{g} / \mathrm{kg}$ ile Giresun ili izlemiștir.

\section{Çay Yaprak Örneklerinin Makro Element Bakımından Genel Durumu ve Dağılımı}

Çizelge 6' da Doğu Karadeniz Bölgesi' nde çay tarımı yapılan alanlardan toprak örnekleri ile birlikte eș zamanlı olarak alınan toplam 532 yaprak örneğinin makro elementler bakımından yeterlik sınırlarına göre sınıflandırıması verilmiștir. Yeterlilik sınıfi Reuters ve Robinson, 1997; Jones, vd., 1991'den yararlanılarak olușturulmuștur.

Doğu Karadeniz Bölgesi' nde yetiștirilen çay bitkisi yaprak örneklerinin toplam azot konsantrasyonu yeterlik sınırlarına göre sınıflandırıldığında \% 3,46'sı az, \% 65,89'u yeterli ve $\% 30,65^{\prime} i$ ise fazla sınıfında yer almıștır. Toplam fosfor konsantrasyonu bakımından ise \% 81,77'si az, \% 17,67'si yeterli ve \% 0,56'sı fazla sınıfında belirlenmiștir. Toplam potasyum konsantrasyonuna göre; yaprak örneklerinin \% 99,62'si az sınıfında

Çizelge 4. Çay bitkisi yaprak örneklerinin toplam N, P, K, Ca ve Mg konsantrasyonlarına ait değerler

Table 4. Values for total $N, P, K$, Ca and Mg concentrations of tea leaf samples

\begin{tabular}{cccccc}
\hline Değerler & $N(g / k g)$ & $P(g / k g)$ & $K(g / k g)$ & $C a ~(g / k g)$ & $M g(g / k g)$ \\
\hline En Düșük & 25,01 & 0,60 & 0,80 & 0,70 & 0,40 \\
\hline En Yüksek & 51,53 & 4,30 & 34,80 & 17,40 & 5,70 \\
\hline Ortalama & 41,24 & 1,70 & 9,40 & 6,10 & 1,80 \\
\hline
\end{tabular}


Çizelge 5. Çay bitkisi yaprak örneklerinin toplam N, P, K, Ca ve Mg konsantrasyonlarına ait bölgesel değerler

Table 5. Regional values for total N, P, K, Ca and Mg concentrations of tea leaf samples

\begin{tabular}{|c|c|c|c|c|c|c|}
\hline III & İlçe & $\mathrm{N}(\mathrm{g} / \mathrm{kg})$ & $P(g / k g)$ & $\mathrm{K}(\mathrm{g} / \mathrm{kg})$ & Ca $(\mathrm{g} / \mathrm{kg})$ & $\mathrm{Mg}(\mathrm{g} / \mathrm{kg})$ \\
\hline \multirow{4}{*}{ 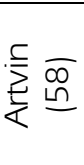 } & Hopa (23) & 38,55 & 1,76 & 9,72 & 5,73 & 1,86 \\
\hline & Borçka (15) & 44,52 & 1,49 & 7,67 & 8,91 & 1,97 \\
\hline & Arhavi (20) & 42,10 & 1,57 & 8,21 & 5,20 & 1,64 \\
\hline & Ortalama & 42,71 & 1,62 & 8,67 & 6,37 & 1,81 \\
\hline \multirow{12}{*}{$\begin{array}{l}\overline{\bar{D}} \\
\frac{m}{0} \\
\frac{N}{2}\end{array}$} & Fındıklı (26) & 42,74 & 1,80 & 8,98 & 7,31 & 1,92 \\
\hline & Ardeșen (52) & 51,29 & 1,58 & 8,85 & 6,88 & 1,86 \\
\hline & Pazar (44) & 41,77 & 1,88 & 9,37 & 6,56 & 2,35 \\
\hline & Hemșin (9) & 34,19 & 2,84 & 8,33 & 12,48 & 2,63 \\
\hline & Cayeli (64) & 59,68 & 2,09 & 9,94 & 7,07 & 2,06 \\
\hline & Merkez (82) & 41,32 & 1,91 & 10,86 & 5,60 & 1,63 \\
\hline & Güneysu (22) & 36,29 & 1,60 & 9,21 & 4,64 & 1,35 \\
\hline & Derepazarı (12) & 51,13 & 1,70 & 11,21 & 3,92 & 1,18 \\
\hline & lyıdere (15) & 57,42 & 1,71 & 10,63 & 4,14 & 1,35 \\
\hline & Kalkandere (30) & 50,16 & 1,61 & 9,93 & 4,30 & 1,37 \\
\hline & İkizdere (5) & 51,29 & 1,46 & 9,32 & 6,20 & 1,70 \\
\hline & Ortalama & 47,58 & 1,84 & 9,83 & 6,18 & 1,81 \\
\hline \multirow{6}{*}{ 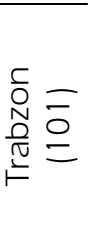 } & Of $(60)$ & 36,61 & 1,35 & 8,32 & 5,39 & 1,48 \\
\hline & Hayrat (17) & 41,94 & 1,51 & 8,91 & 4,96 & 1,40 \\
\hline & Dernekpazarı (3) & 46,29 & 1,23 & 9,20 & 8,60 & 1,60 \\
\hline & Sürmene (15) & 45,00 & 1,38 & 7,87 & 5,03 & 1,53 \\
\hline & Araklı (6) & 42,42 & 1,30 & 8,17 & 8,23 & 1,83 \\
\hline & Ortalama & 46,13 & 1,37 & 8,37 & 5,53 & 1,50 \\
\hline \multirow{3}{*}{ 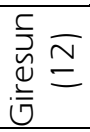 } & Eynesil (5) & 63,39 & 1,38 & 7,86 & 5,90 & 2,38 \\
\hline & Tirebolu (7) & 45,65 & 1,37 & 8,26 & 5,76 & 1,66 \\
\hline & Ortalama & 52,90 & 1,38 & 8,09 & 5,82 & 1,96 \\
\hline
\end{tabular}

yer almıștır. Toplam kalsiyum konsantrasyonu bakımından yaprak örneklerinin \% 17,48'inde kalsiyumun az sınıfta, \% 38,16'sında yeterli sınıfta ve \% 44,36'sında ise fazla sınıfta olduğu belirlenmiștir. Toplam magnezyum konsantrasyonu yeterlik sınırlarına göre sınıflandırılığında yaprak örneklerinin \% 36,09'unda magnezyumun az, \% 58,46 'sının yeterli ve $\% 5,45^{\prime}$ inde fazla sınıfta olduğu belirlenmiștir.

Araștırma sonucunda illere göre; çay yaprak örneklerinin toplam azot konsantrasyonu en az $42,71 \mathrm{~g} / \mathrm{kg}$ ile Artvin ilinde belirlenmiș olup, bunu sırasıyla 46,13 g/kg ile Trabzon, 47,58 g/kg ile Rize ve $52,90 \mathrm{~g} / \mathrm{kg}$ ile Giresun illeri takip etmiștir.Çalıșma kapsamındaki tüm illerden alınan yaprak örneklerinin tamamında fosforun noksan olduğu belirlenmiștir. Trabzon ve Giresun illerinde bu değer \% 100 iken, \% 93, 10 ile Artvin ili ve \% 74,24 ile Rize ili izlemiștir. Artvin, Trabzon ve Giresun' dan alınan yaprak örneklerinin tamamında potasyumun noksan olduğu belirlenmiștir. Bunu \% १९,45 ile Rize ili izlemiștir.

Doğu Karadeniz Bölgesi' nde çay tarımı yapılan Giresun ilinden toprak örnekleri ile birlikte eș zamanlı olarak alınan yaprak örneklerinin tamamında kalsiyumun yeterli ve fazla olduğu belirlenmiștir. Trabzon ilinden alınan yaprak örneklerinin \% 23,76'sında, Rize ilinden alınan yaprak örneklerinin \%16,90'nında ve Artvin ilinden alınan yaprak örneklerinin \% 13,79'unda kalsiyumun noksan düzeyde olduğu belirlenmiștir. Magnezyum bakımından ise, en az magnezyum \% 49,50 ile Trabzon ilinden alınan yaprak örneklerinde belirlenmiștir. Bunu sırasıyla \% 34,63 ile Rize, \% 27,59 ile Artvin ve \% 8,33 ile Giresun illeri izlemiștir (Çizelge 6).

\section{Bazı Toprak ve Bitki Özellikleri Arasındaki ilișkiler}

Toprak-toprak özellikleri arasındaki ilișkiler:

Araștırma kapsamında alınan toprak örneklerinde belirlenen element konsantrasyonları arasında yapılan korelasyon analizlerine göre; toprakların potasyum konsantrasyonları ile $\mathrm{P}$, Ca ve $\mathrm{Mg}$ konsantrasyonları arasında önemli pozitif, kalsiyum konsantrasyonları ile $\mathrm{K}$ ve $\mathrm{Mg}$ konsantrasyonları arasında önemli pozitif, magnezyum konsantrasyonları ile ise $\mathrm{P}$ konsantrasyonları arasında önemli negatif ilișkiler belirlenmiștir (Çizelge 7). 
Çizelge 6. Çay yaprak örneklerinin toplam N, P, K, Ca ve Mg konsantrasyonlarının yeterlik sınırlarına göre dağılımı

Table 6. Distribution of total $\mathrm{N}$, plant available $P, \mathrm{~K}$, Ca and $\mathrm{Mg}$ concentrations of tea leaf samples according to the limits of adequacy

\begin{tabular}{|c|c|c|c|c|c|c|c|}
\hline \multirow{2}{*}{$\begin{array}{c}\text { Makro } \\
\text { Element }\end{array}$} & \multirow{2}{*}{$\begin{array}{c}\text { Sınır Değeri } \\
(\mathrm{g} / \mathrm{kg})\end{array}$} & \multirow{2}{*}{ Sinıf } & \multicolumn{5}{|c|}{ Dağılım \% } \\
\hline & & & Artvin & Rize & Trabzon & Giresun & Genel \\
\hline \multirow{3}{*}{$\mathrm{N}$} & $<38,0$ & $\mathrm{Az}$ & 1,05 & 3,18 & 4,75 & 0 & 3,46 \\
\hline & $38,0-48,0$ & Yeterli & 71,26 & 69,85 & 76,28 & 46,84 & 65,89 \\
\hline & $>48,0$ & Fazla & 27,69 & 26,97 & 18,97 & 53,16 & 30,65 \\
\hline \multirow{3}{*}{$P$} & $<2,0$ & $A z$ & 93,10 & 74,24 & 100 & 100 & 81,77 \\
\hline & $2,0-4,0$ & Yeterli & 6,90 & 24,93 & 0 & 0 & 17,67 \\
\hline & $>4,0$ & Fazla & 0 & 0,83 & 0 & 0 & 0,56 \\
\hline \multirow{3}{*}{ K } & $<18,0$ & $A z$ & 100 & 99,45 & 100 & 100 & 99,62 \\
\hline & $18,0-22,0$ & Yeterli & 0 & 0,28 & 0 & 0 & 0,19 \\
\hline & $>22,0$ & Fazla & 0 & 0,28 & 0 & 0 & 0,19 \\
\hline \multirow{3}{*}{$\mathrm{Ca}$} & $<4,0$ & $A z$ & 13,79 & 16,90 & 23,76 & 0 & 17,48 \\
\hline & $4,0-6,0$ & Yeterli & 36,21 & 38,23 & 37,62 & 50,00 & 38,16 \\
\hline & $>6,0$ & Fazla & 50,00 & 44,88 & 38,61 & 50,00 & 44,36 \\
\hline \multirow{3}{*}{$\mathrm{Mg}$} & $<1,5$ & $\mathrm{Az}$ & 27,59 & 34,63 & 49,50 & 8,33 & 36,09 \\
\hline & $1,5-3,0$ & Yeterli & 68,97 & 58,45 & 49,50 & 83,33 & 58,46 \\
\hline & $>3,0$ & Fazla & 3,45 & 6,93 & 0,99 & 8,33 & 5,45 \\
\hline
\end{tabular}

Çizelge 7. Toprak-toprak özellikleri arasındaki ilișkiler (r)

Table 7. The relationship between soil-soil properties (r)

\begin{tabular}{lllll}
\hline & $\mathrm{P}$ & $\mathrm{K}$ & $\mathrm{Ca}$ & $\mathrm{Mg}$ \\
\hline $\mathrm{K}$ & $0,146^{* * *}$ & & & \\
\hline $\mathrm{Ca}$ & $-0,064$ & $0,460^{* * *}$ & & \\
\hline $\mathrm{Mg}$ & $-0,098^{*}$ & $0,513^{* * *}$ & $0,712^{* * *}$ & $-0,060$ \\
\hline $\mathrm{S}$ & $-0,073$ & 0,005 & 0,013 & \\
\hline
\end{tabular}

* $p<0,05 \quad * * * p<0,001$

Bitki-bitki özellikleri arasındaki ilișkiler: Araștırma kapsamında toprak örnekleri ile eș zamanlı olarak alınan bitki yaprak örneklerinde belirlenen element konsantrasyonları arasında yapılan korelasyon analizlerine göre; yaprak örneklerinin P konsantrasyonları ile K, Ca ve Mg konsantrasyonları arasında önemli pozitif, potasyum konsantrasyonları ile Ca ve Mg konsantrasyonları arasında önemli negatif ve kalsiyum konsantrasyonları ile Mg konsantrasyonları arasında önemli pozitif ilișkiler belirlenmiștir (Çizelge 8).

\section{Toprak-bitki özellikleri arasındaki ilișkiler:}

Araștırma kapsamında alınan toprak örneklerinde ve yaprak örneklerinde belirlenen element konsantrasyonları arasında yapılan korelasyon analizlerine göre; toprak örneklerinde belirlenen fosfor konsantrasyonları ile bitki yaprak örneklerinde belirlenen Ca konsantrasyonları arasında önemli pozitif, toprakların potasyum konsantrasyonları ile yaprakların Mg konsantrasyonları arasında önemli pozitif, toprakların kalsiyum konsantrasyonları ile

Çizelge 8. Bitki-bitki özellikleri arasındaki ilișkiler (r)

Table 8. The relationship between plant-plant properties (r)

\begin{tabular}{|c|c|c|c|}
\hline & $P$ & K & Ca \\
\hline $\mathrm{K}$ & $0,607 * * *$ & & \\
\hline Ca & $0,217^{* * *}$ & $-0,20034 * * *$ & \\
\hline $\mathrm{Mg}$ & $0,224 * * *$ & $-0,118^{* *}$ & $0,602 * * *$ \\
\hline
\end{tabular}


Çizelge 9. Toprak-bitki özellikleri arasındaki ilișkiler (r) )

Table 9. The relationship between soil-plant properties (r)

\begin{tabular}{lccccc}
\hline & $P$ & $K$ & $C a$ & $M g$ & $S$ \\
\hline$P($ Bitki) & 0,053 & 0,026 & 0,012 & $-0,008$ & $0,318^{* * *}$ \\
\hline K (Bitki) & 0,074 & 0,037 & $-0,123^{* *}$ & $-0,095^{*}$ & $0,200^{* * *}$ \\
\hline Ca (Bitki) & $0,109^{*}$ & $-0,009$ & $0,107^{*}$ & 0,043 & 0,063 \\
\hline Mg (Bitki) & $-0,057$ & $0,130^{* *}$ & $0,199^{* * *}$ & $0,290^{* * *}$ & $0,099^{*}$ \\
\hline
\end{tabular}

* $p<0,05 \quad$ ** $p<0,01 \quad$ *** $p<0,001$

yaprakların K konsantrasyonları arasında önemli negatif, Mg konsantrasyonları arasında ise önemli pozitif, toprakların magnezyum konsantrasyonu ile yaprakların K konsantrasyonu arasında önemli negatif, Mg konsantrasyonu ile önemli pozitif ve toprakların kükürt konsantrasyonu ile yaprakların $P$, $\mathrm{K}$ ve $\mathrm{Mg}$ konsantrasyonları arasında önemli pozitif ilișkiler belirlenmiștir (Çizelge 9).

\section{SONUCLAR}

Doğu Karadeniz Bölgesi' nde çay tarımı yapılan toprakların ve çay bitkisi yapraklarının azot, fosfor, potasyum, kalsiyum, magnezyum ve kükürt durumunun belirlenmesini ve potansiyel beslenme problemlerinin ortaya konulmasını amaçlayan bu araștırma sonuçlarına göre; Artvin, Rize, Trabzon ve Giresun illerinde çay tarımı yapılan alanlardan alınan toplam 532 toprak ve toprak örnekleri ile birlikte eș zamanlı alınan yaprak örneklerinde yapılan bir seri analizler sonucu;

a) Çay tarımı yapılan toprakların \% 4,32'sinde azotun, \% 21,99'unda fosforun, \% 37,40'ında potasyumun, \% 70,11'inde kalsiyumun, \% 75.00 'inde magnezyumun, çay bitkisinin ise \% 3,46'sında azotun, $\% 81,77$ 'sinde fosforun, \% 99,62 'sinde potasyumun, $\% 17,48$ 'inde kalsiyumun ve \% 39,06'sında ise magnezyumun noksan düzeyde olduğunun belirlenmesi, üzerinde önemle durulmasını gerektiren sorun olarak ortaya çıktığı görülmüștür. Bu sorunun giderilmesi amaciyla gübreleme programına; yapılacak toprak ve bitki analizleri sonuçlarına göre fosforun, potasyumun, kalsiyumun ve magnezyumun dahil edilmesi gerektiği kanaatine varılmıștır.

b) Çay tarımı yapılan toprakıarın \% 75,75'inde azotun ve \% 57,52'sinde fosfor birikiminin olduğu belirlenmiștir. Bu durum așırı azotun yaratacağı olumsuz çevre sorunları yanında, toprakta pH'nın daha da düșmesine neden olacaktır. Diğer yandan toprakta fosforun fikse olarak yarayıșsız duruma geçmesine neden olması yanında, özellikle çinkonun yarayıșlılığını olumsuz yöne etkilemesi ciddi beslenme problemi yaratacaktır. Bu nedenle

fosforlu gübre kullanımına gereken önemin gösterilmesi ve topraklarda fosfor birikimini önlemek amacıyla așırı fosforlu gübre kullanımından kaçınılmasını gerekmektedir.

c) Toprakta kalsiyum ve magnezyum noksanlığı da önemli bir beslenme problemi yaratacaktır.

d) Toprakta potasyum, kalsiyum ve magnezyumun yetersiz olmasının doğal bir sonucu olarak bitki yapraklarında da bu elementlerin yetersiz düzeyde olduğu belirlenmiștir.

Tüm bu sonuçlar birlikte değerlendirildiğinde, eksikliği belirlenen besin maddelerinin çay bitkisinin gübreleme programına dahil edilmesinin yararlı olacağı, diğer yandan tarla koșullarında gübre çeșidi ve doz denemeleri yapılarak eksikliği görülen besin maddelerinin ne miktarda verilmesi gerektiğinin ortaya konulması ve ayrıca uygun ve etkili gübreleme programının olușturulmasının yöre çay tarımının geleceği bakımından son derece gerekli ve yerinde bir uygulama olacağı kanaatine varılmıștır

\section{Teșekkür}

Bu çalıșma, Ulusal Bor Araștırma Enstitüsü Bașkanlığı tarafından desteklenen 2012-Ç0379 no'lu Proje verilerinden yararlanılarak yapılmıștır.

\section{KAYNAKLAR}

Anonim (2012). İstatistik Bülten, 2012. Cay İșletmeleri Genel Müdürlüğü, Rize, $42 \mathrm{~s}$.

Bardsley CE, Lancaster JD (1965). Methods of Soil Analysis Part 2, Chemical and Microbiological Properties, ed: Black C.A., Amer. Soc. Agr. Inc. Publisher Agronomy Series, No.9, Madison, Wisconsin, USA, pp: $1102-1116$.

Boss CB, Fredeen KJ (2004). Concepts, Instrumentation and Techniques in Inductively Coupled Plasma Optical Emission Spectrometry. PerkinElmer Life and Analytical Sciences, 710 BridgepOrt. Avenue Shelton, CT 06484-4794 USA.

Bray RH, Kurtz LT (1945). Determination of total organic and available forms of phosphorus in soils. Soil Science, 59: 39-45.

Bremner, J.M., 1965. Methods of Soil Analysis. Part 2. Chemical and Microbiological Properties. Ed. C.A. Black. Amer.Soc. Agr. Inc. Publisher Agro. Series No:9. Madison. USA. 
FAO (1990). Micronutrient, Assessment at the Country Level: An International Study. FAO Soil Bulletin by Sillanpaa. Rome.

Jones JR, Wolf B, Mills HA (1991). Plant Analysis Handbook: A Practical Sampling, Preparation, Analysis, and Interpretation Guide. Micro-Macro Publishing, Athens, GA. Micro-Macro Publishing.

Kacar B, Özgümüș A, Katkat $\vee(1978)$. Türkiye'de üretilen çayın ve çay topraklarının potasyum durumu. Uluslar Arası Potas Enstitüsü Türkiye Programı. Araștırma Serisi No: 3. S 1-20.

Kacar B, Özgümüș A, Turan C, Katkat AV, Kayıkçıŏlu i. (1979). Türkiye'de çay tarımı yapılan toprakların ve çay bitkisinin mikro element gereksinmeleri üzerinde bir araștırma. s. 1-67. TÜBITAK, Tarım ve Ormancilık Araștırma Grubu, Kesin Rapor, Proje No. 321, Ankara.

Mahmutoğlu, H (1994). Rize ilinin bazı ekolojik koșullarında seleksiyonla bulunan altı çay (Camellia sinensis L. O Kuntzel klonunun (F-3, M-10. D-7, T-10, G-3 ve P-20) gelișiminin araștırılması projesi. Çay İșletmeleri Genel Müdürlüğü. Rize.

Müftüoğlu NM, Sarımehmet M (1993). Doğu Karadeniz Bölgesi çay tarım topraklarının fosfor miktarları ile ilgili bir araștırma. Ege Üniversitesi Ziraat Fakültesi Dergisi, Cilt: 30, Sayı: 3, 65-72, Bornova-Izmir.

Müftüoğlu NM, Sarımehmet M (1998). Doğu Karadeniz Bölgesinde çay kültürüne alınmıș ve alınmamıș toprakların bazı özellikler yönünden karșılaștırılması. Ziraat Mühendisliği, MayısHaziran, Sayl: 315, 44-46, Ankara.
Pratt P.F (1965), Potassium Methods of Soil, Analysis. Part 2, Amer. soc. of Agro. Inc. Publisher. Medisan, US. s: 1022

Reuter D J, Robinson J B (1997). Plant analysis an interpretation manual. CSIRO Publishing. ISBN: 0643059385 , Collingwood, VIC, Australia.

Sarımehmet M, Müftüoğlu NM (1993). Doğu Karadeniz Bölgesi çay tarım topraklarının organik madde durumu. Ege Üniversitesi Ziraat Fakültesi Dergisi, Cilt: 30, Sayı: 3, 49-56, Bornova-Izmir.

Taban S, Okay Y, Kunter B (2001). Klon ve tohumdan üretilmiș çay bitkisinin farklı hasat dönemlerinde genç ve yașlı yapraklarının bazı kalite özellikleri ile mineral madde içerikleri. Gıda Dergisi, 26, 1, 49-53.

Taban S, Özer P, Turan MA (2006). Çay tarımı yapılan toprakların potansiyel beslenme problemleri ve çayda gübre kullanımı, gübre verim-kalite ilișkisi. I. Rize Sempozyumu, 16-18 Kasım 2006, Rize.

Yurtsever N, Alkan B (1975). Karadeniz Bölgesi topraklarının fosfor intiyaçlarının tayininde kullanılan bazı toprak analiz metodlarının tarla denemeleriyle kalibrasyonu üzerinde bir araștırma. TÜBiTAK Yayınları No: 220, Toag Serino: 36, Ankara. 